and to inquire, as I did, of the experts whether this were so, and what the actual effect might be expected to be. D'ARCY W. Thompson.

February r.

\section{Alpine Strain in the Bengali Pecple.}

In the concluding paragraph of a short notice of my book, "The Indo-Aryan Races," part i., published in NATure, November 23, I9I6, the reviewer writes:-

"The author might with advantage return in his next venture to the original problem of the origin of the Bengalis. He should probably discard Risley's theory of Mongoloid infusion in favour of some early entry of an Alpine strain. If he can establish this doctrine he would do useful service to Indian ethnology" (p. 227).

This is exactly what I have endeavoured to do in chap. ii., entitled "Indo-Aryans of the Outer Countries." After giving my arguments for discarding Risley's classification of the Gujratis, Marathas, and Coorgs as Scytho-Dravidian in type, and the Bengalis and Oriyas as Mongolo-Dravidian, I trace the broadheaded elements among these peoples to one common source, the Homo alpinus of the Pamirs and Chinese Turkestan (pp. 65-71), and later on try to reconstruct the history of the gradual migration of the Alpine invaders from Central Asia over Gujarat, Deccan, Bihar, and Bengal (pp. 75-78). How far I have succeeded in my attempts is for others to judge. I may take this opportunity of adducing fresh evidences relating to the presence of Homo alpinus in Central Asia and of Alpine strain in the Bengali people. In his account of " A Third Journey of Exploration in Central Asia, 1913-16" (from the Geographical Journal of August and September, 1916, p. 29), Sir Aurel Stein writes of the bodies of men and women dug out of graves in the ruins of the Lon-lan site:-

"It was a strange sensation to look down on figures which, but for the parched skin, seemed like those of men asleep, and to feel brought face to face with people who inhabited, and no doubt liked, this dreary Lop-nor region in the first centuries A.D. The features of the heads closely recalled the Homo alpinus type, which, judging from my anthropometric records, worked up by Mr. T. A. Joyce, still supplies the prevalent element in the racial constitution of the indigenous population of Chinese Turkestan, and is seen in its purest form in the Iranian-speaking tribes near the Pamirs."

During the last Christmas holidays, while excavating an old monument near Balurghat, in the Dinajpur district in Bengal, I and my colleagues of the Varendra Research Society had an excellent opportunity of comparing different ethnic types in Bengal. Every day there was a large gathering of men, including highcaste Hindus, Musulmans, Rajbamsis, Mundas, and Santals. The Rajbamsis of the locality are easily distinguished from the rest by their Mongoloid physiognomy, and the Rajbamsis, Mundas, and Santals are all distinguished from the other Hindus and Musulmans by scanty hair on the face. It is, therefore, not possible to explain the origin of the bulk of the Bengalis from an admixture of Mongoloid invaders like the Rajbamsis of Varendra and the Mundas. Santals, and other allied tribes classed by Risley as Dravidian and myself as Nisada. Two other elements in the Indian population, the Hindusthani and the Dravidian of southern India, are both long-headed. So, to explain the presence of broad-heads among the Bengalis, we may very well postulate an Alpine strain. The newly discovered Aryan languages of Turkestan will throw fresh light on the problem.

Varendra Research Society, Rajshahi, Bengal.

\section{SHAKESPEARE'S ENGLAND. ${ }^{1}$}

"SHAKESPEARE'S England" is a very re- markable book, and a credit to our time. It could have been produced in no other. Indeed, it could only have been produced within the last few years, so much is it the outcome of the research in ever so many directions which has been going on of late. It is sad, of course, that it should make its appearance in the middle of the great war, and yet there is something fine and fitting about this. It does not to-day jostle with a motley crowd of ephemeral, flimsy, and flashy tributes. And it has a solemn majesty and solidity which make it worth while, even at such a time, and in virtue of which it will survive even these heavy troubles.

As the first words of the preface justly say, the description of "Shakespeare's England" was a task worth carrying through, even if Shakespeare had never lived. But it is also a contribution of great importance to the understanding of Shakespeare. If Shakespeare was in one sense "not of an age, but for all time," in another he was most essentially of his age. He is emphatically Elizabethan. He could not have been what he was, or written as he did, either a very little earlier or a very little later; either in the days of Wyatt and Surrey, or in those of Milton and Marvell; either in the storm of the Reformation, or in the storm of the Civil War; either before the Tudor expansions, or after the Stuart disillusionments.

To understand him we require to understand his age, and though even a complete knowledge of that marvellous time will not give us Shakespeare, yet it will greatly aid, condition, and correct our ideas of him. And these two remarkably ample and learned volumes tell us how full and exhaustive our knowledge must be. They form, perhaps, the greatest tribute ever paid to Shakespeare. They are wonderfully complete and, for what they give, wonderfully cheap.

To produce them, the labour of a host of specialists has been laid under contribution. All the greater and lesser arts and sciences are dealt with in turn: Theology, Law, Medicine, Poetry, Music, Painting, Acting, Dancing. "The Court, the Camp, the Schools," the Navy, the Army, Sport, Learning and Commerce, Heraldry and Coinage, Rogues and Vagabonds, Bulls and Bears (not of the Stock Exchange, it is true, but of the ring), Astronomy, Astrology, Alchemy-each has its chapter or its section. The illustrations, which are abundant, are excellently chosen and reproduced, and are in themselves at once a delight and an illumination. Ex pede Herculem. One of these appears with this article.

It is not possible within the compass of a brief review even to indicate or inventory half of the wealth to be found in this ample thesaurus. Readers of NATURE will perhaps turn to what is said of the Sciences and of Medicine, of Agricuture and of Gardening. If Bacon had really

1 "Shakespeare's England: An Account of the Life and Manners of his Age." Vol. i., pp. xviii + 546. Vol. ii., pp. $x+610$. (Oxford: At the Clarendon Press, 19t6.) Price, two vols., 25 s, net. No. 2469, VOL. 98] 
written Shakespeare's plays, we might perhaps have expected even more under some of these heads, while we should have expected less under others. But it is just because Shakespeare is Shakespeare that we get so much under all. Nothing seems to escape his "bland and universal eye" or his world-embracing interest.

Medicine, as all know, plays a large part in Shakespeare. He is acquainted with the "congregated College"-i.e. the College of Physicians -brought into existence by Wolsey and Linacre only some fifty years before his own time. He was a contemporary of Harvey. His own son-inlaw was a distinguished physician with a large
In the realm of Zoology Shakespeare seems to have been specially interested in birds. Picturesque creatures, even if imaginary-the phœnix, the unicorn, the salamander, the basilisk, and the cockatrice-naturally find favour with him, as with all poets. Specially interesting and masterly is Sir William Thiselton-Dyer's account of Shakespeare's knowledge of Plants. If Shakespeare introduces a plant, he says, he does it "with faultless inspiration born of observation which no art can supply." England has always possessed a traditional botany, and Shakespeare is here characteristic of England. If he used any book it was probably the "Niewe Herball" of

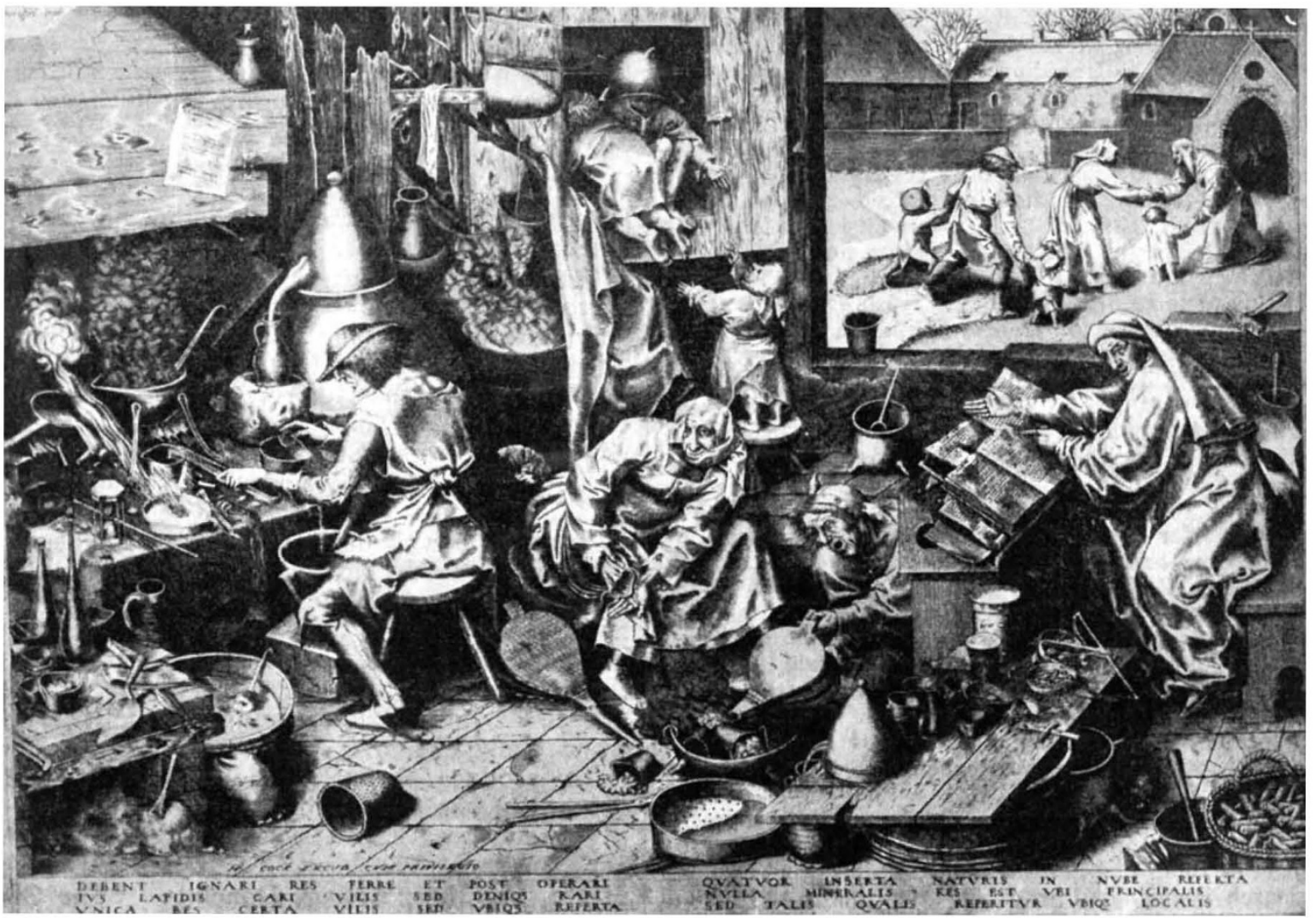

Fı. J.-An alchemist at work. By Pieter Breughel, 1558. From "Shakespeare's England."

and "genteel" practice. It is interesting to be told that mental disease is handled by Shakespeare more skilfully than any other, though it will be no surprise to those who remember their Hamlet; but he shows also a large acquaintance with both maladies and remedies of very varied kinds. His love of technical terms anticipates that of Rudyard Kipling himself.

In Astronomy he was still dominated, it seems, by the Ptolemaic system, and he knew neither that of Copernicus nor that of Bacon, who had his own theory-which Mr. Knobel pronounces to be "mere futility." Alchemy was much encouraged by Queen Elizabeth, but Shakespeare shows only a superficial acquaintance with it. No. 2469 , VOL. 98]
Henry Lyte of Lyte's-Cary. But, as Canon Ellacombe points out, he is curiously distinct from his contemporaries in the use he makes of popular, not literary, botany.

But there are two portions which all must read. Fortunately they come first, and are not likely to escape attention: Sir Walter Raleigh's Preface on the Age of Elizabeth and the Poet Laureate's noble prefatory Ode.

"The age of Elizabeth, the most glorious and in some ways the most significant period of English history," so Sir Walter Raleigh writes of it. What was it like? We of all men ought to understand it. Our hope is we may come to do so yet more fully. For it was the age of the 
Armada and its sequel, an age of menace and peril, of intrigue and then of openly attempted invasion, followed by victory and safety and peaceful expansion. Shakespeare's boyhood knew the first, his flowering and fruiting time coincided with the second. May our young folks find the same experience! That is the theme of Dr. Bridges's Ode. It is a stately, original piece, severe, yet full of chaste beauty, a true British "Pindaric," with the massive masonry and the large, firm ornament of Pindar.

The second movement, to which the first leads up, is splendidly and surprisingly effective. Suddenly towering before us, it seems to scale up and up, higher and higher still, into the empyrean of speculation and philosophy. Then, by a swift but easy turn. it comes to earth again and closes on a quiet, strong, human note, neither exaggerating nor belittling, neither fulsome nor fainthearted, but just, true, beautiful :-

But ye, dear Youth, who lightly in the day of fury

Put on England's glory as a common corat,

And in your stature of masking grace

Stood forth warriors complete,

No praise o'ershadoweth yours to-day,

Walking out of the home of love

To match the deeds of all the dead.-

Alas! Alas! fair Peace,

These were thy blossoming roses,

Look on thy shame, fair Peace, thy tearful shame!

Turn to thine isle, fair Peace; return thou and guard it well?

A cry of the heart, an invocation natural to our time, it will hereafter be its monument and memorial, and no unworthy one. It will wear well, with the book it graces so fitly to-day.

HERBERT WARREN.

\section{THE FUTURE OF FRENCH METALLURGY.}

THE October, 1916, issue of the Bulletin de $t a$ Société d'Encouragement pour l'Industrie Nationale contains the reprint of three lectures delivered under the auspices of that society by Dr. Léon Guillet, the distinguished French metallurgist.

The first lecture is a comparative study of the metallurgy of iron and steel in France and foreign countries; the second deals similarly with the metallurgy of the principal industrial nonferrous metals; and the third treats of the application of science to metallurgical industry. It appears from Dr. Guillet's summary that in $19^{1} 3$ France's position in reference to world output was as follows:- Fourth in steel, eighth in copper and lead, fifth in zinc, fourth in nickel, and second in aluminium production. Her output of tin is very small indeed.

It is natural that considerable anxiety should be felt in France as to the future of her iron and steel production, which is much the most important of her metal industries. By the Treaty of Frankfort, which followed on the FrancoGerman War of 1870-71, Germany obtained, as is well known, the province of Alsace and the NO. 2469, VOL. 98] greater part of Lorraine. It is not, however, so well known that the particular frontier adjustment ultimately adopted in the latter province was based very largely on the evidence furnished by an exact knowledge of its mineral resources possessed by the German Government. As a result of it Germany obtained nineteen iron-mine, sixteen coal-mine, and fourteen other mine concessions, together with the most famous metallurgical establishments of the Moselle basin, and there is little doubt that it was anticipated that a blow was thus being struck at French iron and steel metallurgy from which it would never recover. So little, however, did Thiers realise this that, in addressing the National Assembly, he said :- "Du Fer, il y en a partout en France, d'aussi bon qu'en Suède, et la prospérité de 1'industrie métallurgique dans l'Est est une pure iftusion qui ne durera pas éternellement."

As a result of these frontier rectifications a considerable proportion of the vast "minette" iron-ore deposits which had hitherto been entirely in French territory, apart from the small quantity in Luxemburg, passed into German hands. As their name indicates, they were regarded not merely as worthless, but actually with contempt. This was principally owing to their very high phosphorus content, which rendered them insusceptible of conversion into steel by the acid ptocess, the only one at that time known. In 1878, however, Thomas and Gilchrist, two Englishmen, invented and introduced the "basic" process, by which steel can be dephosphorised. The importance of this discovery to Germany cannot be overrated. It immediately rendered available for steel production the immense resources of "minette" ores which had passed into her hands, and in the highly phosphoric basic slag, which is a by-product in the steel production, she obtained a most valuable agricultural fertiliser. Statues erected to Thomas and Gilchrist in Düsseldorf prove that the German steel manufacturers recognised their debt to these men.

Since 1878 the commercial exploitation of the "minette" ores in French Lorraine, annexed Lorraine, and Luxemburg has proceeded very actively. These deposits constitute by far the largest source of iron and steel production in Europe. Dr. Guillet states that in $19 \mathrm{I}_{2}$ the Meurthe and Moselle basin produced 90'7 per cent. of the French iron-ore minerals; in the same year 78.9 per cent. of the German and Luxemburg iron-ore production was derived from the "minette" ores under their control. Had the Thomas-Gilchrist process been invented eight years earlier there is little doubt that the boundary between France and Germany in the Lorraine "minette" area would have been drawn still farther west.

These facts throw considerable light on the course adopted by Germany at the beginning of the present war. By invading Belgium and pressing on through north-east France in the early weeks of the campaign, the German army obtained possession of that part of France which 